\title{
Gambaran Ulkus Traumatik pada Mahasiswa Pengguna Alat Ortodontik Cekat di Program Studi Kedokteran Gigi Fakultas Kedokteran Universitas Sam Ratulangi
}

\author{
${ }^{1}$ P. S. Anindita, ${ }^{1}$ Bernat Hutagalung, ${ }^{2}$ Sri Kartika P. Manoppo \\ ${ }^{1}$ Program Studi Kedokteran Gigi Fakultas Kedokteran Universitas Sam Ratulangi \\ ${ }^{2}$ Mahasiswa Program Studi Kedokteran Gigi Fakultas Kedokteran Universitas Sam Ratulangi
}

\begin{abstract}
ABSTRAK
Ulkus traumatik merupakan lesi ulseratif pada mukosa mulut yang disebabkan oleh trauma. Salah satu penyebabnya yaitu penggunaan alat ortodontik cekat. Adanya ulkus traumatik dapat menimbulkan ketidaknyamanan pada mulut pasien selama perawatan ortodontik.

Penelitian ini bersifat deskriptif, bertujuan untuk mengetahui gambaran ulkus traumatik pada pengguna alat ortodontik cekat di Program Studi Kedokteran Gigi Fakultas Kedokteran Universitas Sam Ratulangi. Sampel penelitian ini sebanyak 61 orang yang diambil dengan teknik total sampling. Data diperoleh berdasarkan wawancara terhadap responden.

Hasil penelitian menunjukkan bahwa 90,1\% mahasiswa pengguna alat ortodontik cekat di PSKG FK-UNSRAT pernah mengalami ulkus traumatik, dimana perempuan lebih banyak mengalami ulkus dibandingkan laki-laki. Sebanyak $60 \%$ responden menyatakan ulkus pertama kali terjadi pada periode $<1$ bulan setelah penggunaan alat. Lokasi terjadinya ulkus yaitu pada mukosa pipi $80 \%$ dan mukosa bibir $20 \%$. Penyebab ulkus traumatik yang paling sering yaitu kawat (56,3\%). Ulkus yang terjadi dengan frekuensi tidak teratur ditemui pada $72,7 \%$ responden. Sebanyak 43,7\% responden membiarkan ulkus tanpa perawatan, $12,7 \%$ berobat ke dokter gigi dan $40 \%$ responden mengobati sendiri, dimana $63 \%$ diantaranya menggunakan obat topikal.
\end{abstract}

Kata kunci: ulkus traumatik, alat ortodontik cekat.

\section{ABSTRACT}

Traumatic ulcer is an oral mucosa ulcerative lesion caused by trauma. One of the causes is the using of fixed orthodontic appliance. Traumatic ulcer can give an uncomfortable feeling to the patients during the orthodontic treatment.

This is a descriptive study that aims to know the traumatic ulcer of the fixed orthodontic appliance users in dentistry student of Medical Faculty Sam Ratulangi University. The samples were 61 people taken by total sampling technique. Data was obtained by interviewing the respondent.

The result showed that $90.1 \%$ of orthodontic patients had experienced traumatic ulcer, more girls than boys. About 60\% respondents had experienced the ulcer for the first time at period < 1 month after application. The location of traumatic ulcer in buccal mucosa is $80 \%$ and lip mucosa $20 \%$. The most common cause of traumatic ulcer is wire (56\%). Ulcer with irregular frequency found in $72.7 \%$ respondents. About $43.7 \%$ respondents left the ulcer untreated, $12.7 \%$ made dental visit, and about $40 \%$ made self-treating which $63 \%$ of them used topical medicine.

Keywords: traumatic ulcer, fixed orthodontic appliance.

Korespondensi: Sri Kartika P. Manoppo, Program Studi Kedokteran Gigi, Fakultas Kedokteran Universitas Sam Ratulangi, Manado, Indonesia. E-mail: ikhaix@gmail.com

\section{PENDAHULUAN}

Ulkus merupakan lesi yang terbentuk oleh kerusakan lokal dari jaringan epitelium. ${ }^{1}$ Ulkus yang terbentuk di mukosa mulut merupakan gambaran lesi oral yang sangat umum dijumpai pada kebanyakan orang di berbagai usia maupun jenis kelamin. Prevalensi terjadinya ulkus $25 \%$ dari populasi di dunia. ${ }^{2}$ 
Salah satu penyebab ulkus yang paling sering yaitu trauma. ${ }^{1}$ Prevalensi ulkus traumatik cukup tinggi dibandingkan lesi-lesi mulut lainnya. Penelitian yang dilakukan oleh Castellanos, dkk. pada tahun 2003 di Meksiko terhadap 1000 orang menunjukkan prevalensi ulkus traumatik sebesar $40,24 \% .{ }^{3}$ Cebeci, dkk. dalam penelitiannya pada tahun 2005 di Turki mendapati prevalensi ulkus traumatik mencapai $30,47 \%{ }^{4}$

Ulkus traumatik dapat terjadi karena trauma fisik, termal, maupun kimiawi. Penggunaan alat ortodontik termasuk salah satu faktor fisik yang menyebabkan ulkus traumatik. Perawatan ortodontik dengan alat cekat banyak menggunakan komponen yang dapat menimbulkan trauma pada jaringan mulut. Pembuatan alat yang kurang baik yang ditunjang oleh kurangnya pengertian dan sikap pasien yang tidak kooperatif dapat menimbulkan resiko trauma pada mukosa mulut yang akhirnya akan menimbulkan ulkus traumatik. $^{5,6}$ Akibat dari timbulnya ulkus traumatik yaitu rasa nyeri, kesulitan mulut untuk beraktivitas dan ketidaknyamanan pasien yang dapat mengganggu proses perawatan.

Beberapa penelitian menunjukkan bahwa ulkus merupakan keluhan utama dalam perawatan ortodontik. Singh pada tahun 2008 di New Delhi menunjukkan bahwa keluhan terjadinya ulkus traumatik selama perawatan ortodontik sebesar $56 \%$. $^{7}$ Kvam, dkk. pada tahun 1987 di Norwegia mendapati bahwa $28,7 \%$ dari 161 pasien mengeluhkan terkena ulserasi, dimana $75,8 \%$ diantaranya mengalami ulserasi ringan, sedangkan $2,5 \%$ mengalami ulserasi berat. ${ }^{8}$

Penelitian mengenai ulkus traumatik di Indonesia masih sangat jarang karena penyakit ini masih dianggap bukan masalah yang serius sehingga kurang mengundang perhatian. Ulkus traumatik memang biasanya dapat hilang dalam beberapa hari jika penyebabnya dihilangkan, namun jika trauma terjadi secara berulang dan tidak diatasi, maka ulkus akan bertambah parah. Trauma kronis pada mukosa mulut dapat menyebabkan ulkus akan berkembang hingga bisa berakibat terjadinya hiperplasia atau hiperkeratosis mukosa. ${ }^{6}$ Resiko yang besar ini tentu tidak dapat disepelekan oleh pasien maupun dokter gigi.

Para calon dokter gigi biasanya memiliki perhatian lebih terhadap masalah kesehatan gigi dan mulut sehingga banyak yang tertarik untuk melakukan perawatan gigi, salah satunya perawatan ortodontik cekat. Di antara para pengguna alat ortodontik cekat pada mahasiswa Program Studi Kedokteran Gigi Fakultas Kedokteran Universitas Sam Ratulangi (PSKG FK-UNSRAT) banyak ditemukan keluhan timbulnya ulkus traumatik saat pemakaian alat ini.

Penelitian ini bertujuan untuk mengetahui gambaran ulkus traumatik pada mahasiswa pengguna alat ortodontik cekat di PSKG FKUNSRAT.

\section{BAHAN DAN METODE}

Penelitian dilakukan di PSKG FK-UNSRAT yang dilaksanakan pada bulan Juli 2013. Populasi yaitu mahasiswa pengguna alat ortodontik cekat di PSKG FK-UNSRAT angkatan 2005 sampai dengan 2012. Dengan menggunakan total sampling diperoleh sampel sebanyak 61 orang. Cara pengumpulan data yaitu melalui wawancara terhadap responden berdasarkan kuesioner yang ada. Data diolah kemudian disajikan dalam bentuk tabel distribusi frekuensi.

\section{HASIL PENELITIAN}

Penelitian dilakukan pada mahasiswa dan mahasiswa profesi di PSKG FK-UNSRAT sebanyak 61 orang yang diambil dari delapan angkatan yaitu angkatan 2005 (4 orang), angkatan 2006 (21 orang), angkatan 2007 (2 orang), angkatan 2008 (3 orang), angkatan 2009 (5 orang), angkatan 2010 (6 orang), angkatan 2011 (7 orang) dan angkatan 2012 (13 orang).

Distribusi frekuensi ulkus traumatik pada mahasiswa pengguna alat ortodontik cekat berdasarkan jenis kelamin, waktu terjadinya, lokasi, penyebab, frekuensi, dan cara penanganan responden dapat dilihat pada tabel berikut: 
Tabel 1. Distribusi frekuensi ulkus traumatik berdasarkan jenis kelamin

\begin{tabular}{ccccccc}
\hline \multirow{2}{*}{ Jenis Kelamin } & \multicolumn{4}{c}{ Ulkus traumatik } & \multicolumn{2}{c}{ Total } \\
& \multicolumn{2}{c}{ (Pernah) } & \multicolumn{2}{c}{ (Tidak Pernah) } & \multicolumn{2}{c}{} \\
\cline { 2 - 7 } & $\mathrm{n}$ & $\%$ & $\mathrm{n}$ & $\%$ & $\mathrm{n}$ & $\%$ \\
\hline Laki-laki & 8 & 88,9 & 1 & 11,1 & 9 & 100 \\
Perempuan & 47 & 90,3 & 5 & 9,7 & 52 & 100 \\
\hline Total & 55 & 90,1 & 6 & 9,9 & 61 & 100 \\
\hline
\end{tabular}

Tabel 2. Distribusi frekuensi ulkus traumatik berdasarkan waktu terjadinya

\begin{tabular}{ccc}
\hline Waktu Terjadinya & $\begin{array}{c}\text { Ulkus Traumatik } \\
(\mathrm{n})\end{array}$ & $\%$ \\
\hline$<1$ bulan setelah penggunaan alat & 33 & 60 \\
\hline $1-6$ bulan setelah penggunaan alat & 14 & 25,4 \\
\hline 7 - 12 bulan setelah penggunaan alat & 5 & 9,1 \\
\hline$>12$ bulan setelah penggunaan alat & 3 & 5,5 \\
\hline Total & 55 & 100 \\
\hline
\end{tabular}

Tabel 3. Distribusi frekuensi ulkus traumatik berdasarkan lokasinya

\begin{tabular}{|c|c|c|}
\hline Lokasi Ulkus Traumatik & $\begin{array}{c}\text { Ulkus Traumatik } \\
(\mathrm{n})\end{array}$ & $\%$ \\
\hline Mukosa bibir & 11 & 20 \\
\hline Mukosa pipi & 44 & 80 \\
\hline Lidah & 0 & 0 \\
\hline Gingiva & 0 & 0 \\
\hline Total & 55 & 100 \\
\hline
\end{tabular}

Tabel 4. Distribusi frekuensi ulkus traumatik berdasarkan penyebabnya

\begin{tabular}{|c|c|c|}
\hline Penyebab Ulkus Traumatik & $\begin{array}{l}\text { Ulkus Traumatik } \\
\text { (n) }\end{array}$ & $\%$ \\
\hline Bracket & 21 & 38,2 \\
\hline Band tube & 3 & 5,5 \\
\hline Kawat/wire & 31 & 56,3 \\
\hline Lock-pins & 0 & 0 \\
\hline Total & 55 & 100 \\
\hline
\end{tabular}

Tabel 5. Distribusi frekuensi ulkus traumatik berdasarkan frekuensi terjadinya

\begin{tabular}{lcc}
\multicolumn{1}{c}{ Frekuensi } & $\begin{array}{c}\text { Ulkus Traumatik } \\
(\mathrm{n})\end{array}$ & $\%$ \\
\hline Dua minggu sekali & 2 & 3,6 \\
\hline Sebulan sekali & 10 & 18,2 \\
\hline Enam bulan sekali & 3 & 5,5 \\
\hline Tidak teratur & 40 & 72,7 \\
\hline \multicolumn{1}{c}{ Total } & 55 & 100 \\
\hline
\end{tabular}


Tabel 6. Distribusi frekuensi ulkus traumatik berdasarkan cara penanganannya

\begin{tabular}{lcc}
\hline \multicolumn{1}{c}{ Cara Penanganan } & $\begin{array}{c}\text { Ulkus Traumatik } \\
(\mathrm{n})\end{array}$ & $\%$ \\
\hline Dibiarkan tanpa obat & 24 & 43,7 \\
\hline Mengobati sendiri & 22 & 40 \\
\hline Ke dokter umum & 2 & 3,6 \\
\hline Ke dokter gigi & 7 & 12,7 \\
\hline \multicolumn{1}{c}{ Total } & 55 & 100 \\
\hline
\end{tabular}

Tabel 7. Distribusi frekuensi ulkus traumatik berdasarkan cara mengobati sendiri

\begin{tabular}{lcc}
\hline \multicolumn{1}{c}{ Pengobatan Sendiri } & $\begin{array}{c}\text { Ulkus Traumatik } \\
(\mathrm{n})\end{array}$ & $\%$ \\
\hline Obat kumur & 5 & 22,8 \\
\hline Obat topikal & 14 & 63,6 \\
\hline Minum obat analgetik & 3 & 13,6 \\
\hline Minum obat antibiotik & 0 & 0 \\
\hline Total & 22 & 100 \\
\hline
\end{tabular}

\section{PEMBAHASAN}

Hasil penelitian distribusi ulkus traumatik berdasarkan jenis kelamin (Tabel 1) menunjukkan bahwa ulkus traumatik akibat penggunaan alat ortodontik cekat lebih banyak dialami oleh perempuan dibandingkan laki-laki. Hal ini serupa dengan penelitian yang dilakukan oleh Singh pada tahun 2008 dan Kvam dkk. pada tahun 1989 dimana mereka mendapati perempuan lebih banyak mengalami ulkus traumatik akibat alat ortodontik cekat dibandingkan laki-laki. ${ }^{7,9}$ Beberapa penelitian (Gaphor dkk. tahun 2011, Cebeci dkk. tahun 2009, Mathew dkk. tahun 2008) mengenai lesi mukosa mulut mendapati insidensi ulkus traumatik pada mukosa mulut lebih sering dijumpai pada perempuan dibandingkan laki-laki. ${ }^{4,10,11}$

Hal ini dapat dikaitkan dengan faktor hormonal, dimana hormon yang dapat berpengaruh yaitu hormon estrogen. Hormon ini lebih banyak terdapat pada perempuan daripada laki-laki. Reseptor estrogen banyak ditemukan pada mukosa mulut yaitu gingiva dan epitel bukal pada perempuan. Jaringan lunak mulut pada perempuan diketahui sensitif terhadap perubahan hormonal. Meningkatnya hormon estrogen pada masa pubertas atau kehamilan dapat menyebabkan lebih rentannya mukosa mulut terhadap terjadinya luka atau inflamasi. ${ }^{12}$
Distribusi ulkus traumatik berdasarkan waktu terjadinya (Tabel 2) menunjukkan bahwa terjadinya ulkus traumatik yang pertama kali paling banyak terjadi pada periode $<1$ bulan setelah penggunaan alat (60\%). Hal ini didukung oleh penelitian yang dilakukan Kavaliauskiene dkk. pada tahun 2012 yang menemukan bahwa dari 93 pasien yang menjadi subjek penelitian, semuanya ditemui adanya lesi akibat trauma pada mukosa mulut selama 1 bulan penggunaan alat ortodontik cekat setelah insersi. Rata-rata perubahan mukosa mulut sudah mulai terlihat pada periode $2-3$ jam setelah insersi alat dengan lesi ringan dan hal tersebut mulai meningkat hingga periode $1-7$ hari. ${ }^{13} \mathrm{Hal}$ tersebut juga sesuai dengan yang dikutip dari Singh dkk. tahun 2008 dimana ulkus traumatik biasanya terjadi pada minggu pertama penggunaan alat ortodontik cekat.

Periode < 1 bulan penggunaan alat merupakan periode awal, dimana pada periode ini mulut masih dalam tahap penyesuaian dengan alat ortodontik yang digunakan. Menurut penelitian Mei dkk. pada tahun 2013, komponen alat ortodontik seperti kawat dan bracket memengaruhi keadaan mukosa mulut saat penyesuaian dengan alat tersebut. Mereka menemukan bahwa saat penyesuaian dengan alat, terlihat adanya perubahan pada mukosa berupa hiperplasia dan hiperkeratosis epitel 
ringan sebagai respon dari stimulus mekanik dari alat ortodontik. ${ }^{14}$

Selain itu, pada periode ini keadaan gigi geligi yang akan dikoreksi belum mengalami perubahan sehingga komponen alat ortodontik yang ditempatkan pada gigi dengan kondisi tertentu (misalnya bukoversi atau labioversi) dapat beresiko menyebabkan terjadinya ulkus traumatik. Sebaliknya, semakin lama suatu penggunaan alat ortodontik maka kemungkinan terjadinya ulkus traumatik semakin kecil. Hal ini dikaitkan dengan keadaan mukosa mulut yang sudah lebih dapat beradaptasi dengan alat yang digunakan, serta keadaan gigi geligi yang kurang rapi sehingga resiko terjadinya ulkus traumatik semakin kecil.

Data penelitian berdasarkan lokasi ulkus traumatik (Tabel 3) menunjukkan bahwa lokasi ulkus traumatik yang paling sering yaitu mukosa pipi dengan persentase $80 \%$, sedangkan pada mukosa bibir $20 \%$ dan tidak terjadi pada lidah serta gingiva. Hal ini serupa dengan penelitian yang oleh Kvam dkk. pada tahun 1987 dan 1989 yang melaporkan 76\% dan $95 \%$ pasien mengalami ulkus traumatik di mukosa pipi selama perawatan ortodontik. ${ }^{8,9}$

Fungsi dasar mukosa yaitu sebagai barrier, melanjutkan sensasi dari lingkungan luar, pengatur panas dan medium disekresikannya saliva. Epitel permukaan mukosa membentuk barrier utama terhadap berbagai keadaan fisik dan kimia. Keratinisasi merupakan suatu bentuk perlindungan terhadap penyesuaian fungsi dari rangsangan atau iritasi. ${ }^{15}$

Mukosa di dalam rongga mulut ada yang berkeratin maupun yang tidak berkeratin. ${ }^{15}$ Mukosa gingiva merupakan mukosa mastikasi dimana epitelnya merupakan epitel berkeratin, dengan vaskularisasi sedang. Jaringan ikat kolagen pada mukosa ini lebih padat, tebal dan teratur dibandingkan dengan jaringan ikat kolagen pada mukosa penutup. Mukosa pipi, bibir dan ventral lidah termasuk dalam mukosa penutup yang sifatnya fleksibel. Epitel pada mukosa ini merupakan epitel skuamosa berlapis yang tidak berkeratin, sedangkan lamina proprianya terdiri dari serat kolagen yang elastis dan retikular. ${ }^{15,16,17} \mathrm{Hal}$ tersebut menyebabkan mukosa pipi, bibir dan ventral lidah lebih rentan terhadap terjadinya ulkus saat terjadi trauma. Pemakaian alat ortodontik dalam penelitian ini lebih banyak menimbulkan trauma yang disebabkan oleh kawat pada bagian distal, atau kawat yang tajam dan kasar sehingga dapat menyebabkan ulkus pada mukosa pipi.

Hasil penelitian berdasarkan penyebab ulkus traumatik (Tabel 4) menunjukkan bahwa kawat/wire merupakan komponen yang paling sering menyebabkan ulkus traumatik dengan persentase $56,3 \%$. Hal ini sesuai dengan yang dikutip dari Roopesh dkk. pada tahun 2013 yang menyatakan bahwa salah satu keluhan yang paling sering dilaporkan oleh pasien ortodontik yaitu iritasi akibat kawat. ${ }^{18}$ Namun berbeda dengan penelitian yang dilakukan oleh Kavaliauskiene dkk. pada tahun 2012 yang mendapati bracket sebagai komponen alat ortodontik yang paling banyak menyebabkan ulkus traumatik. ${ }^{13}$ Perbedaan ini disebabkan oleh perbedaan dokter gigi dan perilaku pasien, dimana pada penelitian Kavaliauskiene dkk. sebagian besar ulkus terjadi karena rusak dan terlepasnya bracket, sedangkan pada penelitian ini hal tersebut tidak banyak ditemukan.

Sebagian besar komponen alat ortodontik cekat terbuat dari logam stainless steel dengan kandungan $6-12 \%$ nikel (Ni) dan $15-22 \%$ kromium (Cr). ${ }^{16,19}$ Kawat/wire merupakan komponen yang berada pada semua bagian dari alat ortodontik cekat, yaitu termasuk archwire, ligature wire dan hook. Menurut penelitian yang dilakukan oleh Faccioni dkk. pada tahun 2004, terdapat peningkatan nikel yang dapat merangsang kerusakan DNA pada mukosa mulut. ${ }^{20}$ Hal ini dapat lebih memungkinkan terjadinya ulserasi pada mukosa mulut yang rentan terhadap terjadinya trauma.

Selain itu berbagai kondisi penyebab terjadinya ulserasi yang sering ditemui diantaranya iritasi akibat loop yang terdapat pada archwire, ligature wire, panjangnya kawat bagian distal, korosif dan kasarnya permukaan kawat, serta rusaknya komponen alat seperti terlepasnya kawat dari buccal tube molar, terlepasnya bracket dan lain-lain. ${ }^{18,21}$ Laporan kasus oleh Bishara pada tahun 1995 menyebutkan seorang pasien mengeluhkan sakit dan iritasi pada mukosa pipi. Hasil pemeriksaan menunjukkan lesi ini terjadi akibat kawat yang kasar dan terjadinya korosif pada komponen tersebut. ${ }^{21}$ Rasool dkk. pada tahun 2013 dalam penelitiannya menunjukkan 
bahwa pada 59,3\% pasien didapati terjadi kerusakan pada komponen alat ortodontik yang dipakai, dimana salah satu akibat yang terjadi yaitu ulkus traumatik. Kerusakan yang terjadi diakibatkan oleh kurangnya kontrol dokter gigi selama pemasangan alat, serta kurangnya kesadaran dan kehati-hatian pasien selama penggunaan alat. ${ }^{22}$

Panjangnya kawat pada bagian distal dapat menyebabkan terjadinya ulkus traumatik. Hal ini dikarenakan pada saat perawatan, gigigeligi biasanya akan tertarik dan merapat sehingga kawat utama (archwire) menjadi lebih panjang pada bagian distal. Ini dapat menyebabkan iritasi pada mukosa di daerah kawat tersebut.

Hasil penelitian ini menunjukkan persentase ulkus traumatik yang disebabkan oleh band tube sangat kecil. Hal ini dikarenakan pengaruh band tube untuk menyebabkan trauma pada mukosa mulut tidak cukup besar jika dibandingkan dengan komponen lainnya. Ini sesuai dengan penelitian Arruda dkk. pada tahun 2011 yang mendapati pengaruh band tube terhadap mukosa mulut lebih kecil jika dibandingkan bracket. $^{23}$ Tidak ditemukannya ulkus traumatik yang disebabkan oleh lock-pins dalam penelitian ini, karena pada jenis alat ortodontik yang digunakan responden tidak terdapat komponen lock-pins.

Distribusi ulkus traumatik berdasarkan frekuensi terjadinya (Tabel 5) menunjukkan bahwa sebagian besar responden menyatakan ulkus traumatik terjadi tidak teratur. Terjadinya ulkus traumatik tergantung pada seberapa rentan mukosa mulut seseorang dan seberapa baik komponen alat yang digunakan. ${ }^{7,14}$ Menurut penelitian yang dilakukan oleh Mei dkk. pada tahun 2013 dan Pareira dkk. pada tahun 2009, saat terjadi gesekan antara alat ortodontik dengan mukosa mulut akan terjadi perubahan sel epitel mukosa. Perubahan tersebut merupakan bagian dari proses penyesuaian mukosa dengan alat. ${ }^{14,15}$

Arruda dkk. dalam penelitiannya pada tahun 2011 mengenai perubahan sel epitel mukosa mulut akibat alat ortodontik, menemukan bahwa kontak yang terjadi antara alat ortodontik dengan mukosa menyebabkan berkurangnya nukleus dan sitoplasma, yang secara histologi reaksi selular ini dikenal dengan atrofi. Atrofi merupakan respon adaptif yang dapat menyebabkan berkurangnya suplai darah, nutrisi yang tidak adekuat, hipoksia dan tekanan. Terkait dengan efek-efek tersebut, atrofi sel dapat meningkat sampai pada kondisi dimana sel terluka dan mati. ${ }^{23}$

Ulkus yang disebabkan karena penyesuaian mukosa dengan alat biasanya terjadi pada saat adanya pergantian komponen alat. Pergantian komponen alat ini dilakukan operator melalui kontrol pasien setiap dua minggu sekali, sebulan sekali, atau enam bulan sekali, namun pada kebanyakan responden dalam penelitian ini, ulkus hanya terjadi jika ada kerusakan pada alat ortodontik atau terdapat komponen tertentu yang dapat menyebabkan iritasi mukosa sehingga frekuensinya tidak teratur.

Hasil penelitian berdasarkan cara penanganan ulkus (Tabel 6) menunjukkan bahwa $43,7 \%$ responden membiarkan tanpa perawatan terhadap ulkus yang dialami. Hal ini dikarenakan ulkus biasanya dapat sembuh sendiri tanpa perawatan dalam kurun waktu 7 - 14 hari. Selain itu juga, banyak orang menganggap ulkus traumatik bukan masalah yang serius sehingga penanganan ulkus masih dianggap tidak perlu kecuali ulkus menyebabkan ketidaknyamanan yang besar saat beraktivitas.

Sebanyak $40 \%$ responden melakukan perawatan dengan mengobati sendiri dan hanya sebagian kecil yang pergi ke dokter gigi. Hal ini sesuai dengan yang dikutip dari Menteri Kesehatan Republik Indonesia yang menyatakan bahwa perilaku masyarakat Indonesia dalam mengobati penyakit mulutnya yaitu hanya dengan mengobatinya sendiri dan jarang pergi ke dokter. ${ }^{24}$ Penanganan ulkus traumatik ditujukan untuk mempercepat sembuhnya ulkus, mengurangi rasa sakit, atau mencegah terjadinya infeksi atau lebih parahnya ulkus. ${ }^{6}$

Hasil penelitian ini menunjukkan bahwa dari 22 orang yang melakukan pengobatan sendiri (Tabel 7), responden paling banyak menggunakan obat topikal yaitu $63,6 \%$ sedangkan persentase penggunaan obat minum sangat kecil. Hal ini serupa dengan yang dikutip dari Gupta dkk. tahun 2012 dimana obat yang paling banyak digunakan untuk mengobati ulserasi pada mulut yaitu 
topikal steroid $(45 \%)$ sedangkan yang paling sedikit yaitu pemakaian antibiotik dan analgesik $(19 \%) .{ }^{25}$

Hasil penelitian ini juga menunjukkan bahwa responden lebih banyak memilih menggunakan obat topikal daripada obat kumur. Hal ini dapat disebabkan oleh tingkat efektivitas dalam penyembuhan ulkus, dimana sesuai dengan penelitian yang dilakukan oleh Mostafa dan Ibrahem pada tahun 2009 yang mendapati bahwa penggunaan obat topikal lebih efektif dibandingkan obat kumur, baik dalam mengurangi intensitas rasa sakit maupun dalam proses penyembuhan ulkus. ${ }^{26}$

Menurut literatur, penggunaan topikal kortikosteroid dianjurkan untuk pengobatan terhadap ulserasi pada mukosa mulut. Topikal kortikosteroid berfungsi sebagai agen antiinflamasi. Topikal kortikosteroid dapat berupa triamcinolone acetonide $0,1 \%$, kenalog in orabase, salep hydrocortisone acetate $1 \%$ dan salep bethamethasone dipropionate $0,05 \% .^{27}$ Berdasarkan hasil tersebut, dapat dilihat bahwa penanganan responden baik terhadap ulkus yang mereka derita.

\section{SIMPULAN}

Gambaran ulkus traumatik pada mahasiswa pengguna alat ortodontik cekat di PSKG FK-UNSRAT menunjukkan sebagian besar pernah mengalami ulkus traumatik, dan yang terbanyak pada perempuan $(90,3 \%)$. Ulkus pertama kali terjadi pada periode $<1$ bulan setelah penggunaan alat $(60 \%)$. Lokasi yang paling sering terkena yaitu mukosa pipi $(80 \%)$. Penyebab ulkus yang paling sering yaitu trauma akibat kawat $(56,3 \%)$. Ulkus terjadi dengan frekuensi tidak teratur $(72,7 \%)$. Responden paling banyak membiarkan ulkus tanpa pengobatan $(43,7 \%)$, sedangkan $40 \%$ responden mengobati sendiri dimana $63 \%$ diantaranya menggunakan obat topikal.

\section{DAFTAR PUSTAKA}

1. Regezi JA, Sciubba JJ, Jordan RCK. Oral pathology: Clinical pathologic correlations $5^{\text {th }}$ ed. New York: Elsevier; 2008. p. 22-3.

2. Paleri V, Staines K, Sloan P, Douglas A, Wilson J. Evaluation of oral ulceration in primary care. BMJ [serial online] 2010 [cited 2013 Apr 8]; 340: 1234-9. Available from: URL: http://aspc-
uk.net/.../Evaluation $\% 200 f \% 20$ Oral $\% 20$

Ulcers\%20In\%20Primary\%20Care.pdf

3. Castellanos JL, Guzman LD, Guanajuato. Lesions of the oral mucosa: an epidemiological study of 23785 Mexican patiens. Mosby [serial online] 2008 [cited 2013 May 20]; 78-85. Available from URL:

http://oralpathol.dlearn.kmu.edu.tw/case/J ournal\%20reading-intern-08-

03/oral\%20mucosa\%20lesionepidemiological\%20study-OOOE2008.pdf

4. Cebeci ARI, Gulsahi A, Kamburoglu K, Orhan BK, Oztas B. Prevalence and distribution of oral mucosal lesions in an adult turkish population. Med Oral Patol Oral Cir Bucal [serial online] 2009 [cited 2013 May 20]; 14(6): 272-7. Available from URL: http://www.medicinaoral.com/medoralfre e01/v14i6/medoralv14i6p272.pdf

5. Yordan B, Prihandini. Efek pasta gigi non detergen pada gingivitis dan stomatitis aphtosa pemakai alat cekat. MIKGI. 2003; 10(5): 259-62.

6. Scully C, Porter S, Porter SR. Orofacial Disease: Update for the dental clinical team. Barcelona: Churchill Livingstone; 2003. p. 11-2.

7. Singh G. Textbook of Orthodontics $2^{\text {nd }}$ ed. New Delhi: JBP; 2008. p. 316-8, 450.

8. Kvam E, Gjerdet NR, Bondevik O. Traumatic ulcer and pain during orthodontic treatment. Community Dent Oral Epidemiol [serial online] 1987 [cited 2013 Apr 10]; 15(2): 104-7. Available from:

URL: http://www.ncbi.nlm.nih.gov/pubmed/347 1374

9. Kvam E, Bondevik O, Gjerdet NR. Traumatic ulcer and pain in adults during orthodontic treatment. Community Dentistry and Oral Epidemiology [serial online] 1989 [cited 2013 Apr 10]; 17(3): 154-7. Available from: URL:http://www.ncbi.nlm.nih.gov/pubme $\mathrm{d} / 2736897$

10. Gaphor SM, Abdullah MJ. Prevalence, sex distribution of oral lesions in patients attending an oral diagnosis clinic in Sulaimani University. J Bagh College Dentistry [serial online] 2011 [cited 2013 
Aug 29]; 23(3): 67-73. Available from: URL:

http://www.codental.uobaghdad.edu.iq/up loads/journal/Shanaz\%20Final.pdf

11. Mathew AL, Pai KM, Sholapurkar AA, Vengal $M$. The prevalence of oral mucosal lesions in patients visiting a dental school in Southern India. Indian $\mathbf{J}$ Dent Res [serial online] 2008 [cited 2013 Aug 29]; 19(2): 99-103. Available from: URL:

http://www.ijdr.in/article.asp?issn=09709290; year $=2008$; volume $=19$; issue $=2$; spag $\mathrm{e}=99$; epage $=103$; aulast=Mathew

12. Anonim. Women's oral health issues. ADA [serial online] 2006 [cited 2013 Aug 29]; 1-39. Available from: URL: http://www.ada.org/sections/professional Resources/pdfs/healthcare_womens.pdf

13. Kavaliauskiene A, Smailiene D, Buskiene I, Keriene D. Pain and discomfort perception among patients undergoing orthodontic treatment: result from one month follow up study. Stomatologija, Baltic Dental and Maxillofacial Journal [serial online] 2012 [cited 2013 Sept 24]; 14(4): 118-25. Available from: URL: http://www.sbdmj.com/124/124-04.pdf

14. Mei RM, Lima AA, Filho JC, Tanaka OM, Filho OG, Camargo ES. A cytological analysis of the oral mucosa adjacent to orthodontic devices. Europ J of GenDent. 2013; 2(2): 119-123.

15. Avery JK. Oral development and histology $3^{\text {rd }}$ ed. New York: Thieme; 2001. p. 248-273.

16. Pareira BR, Tanaka OM, Lima AA, Maruo OG, Carmago ES. Metal and ceramic bracket effect on human bucal mucosa ephitelial cells. The Angle Orthodontist [serial online] 2009 [cited 2013 Aug 1]; 79(2): 373-9. Available from:

URL: http://www.angle.org/doi/pdf/10.2319/021 508-92.1

17. Kahn MA. Oral exfoliative cytology procedures: conventional brush biopsy and ThinPrep. J Tenn Dent Assoc [serial online] 2001 [cited 2013 Aug 1]; 81: 1720. Available from: URL: http://www.unboundmedicine.com/eviden ce/ub/citation/11324194/Oral_exfoliative _cytology_procedures:_conventional_bru sh_biopsy_and_ThinPrep_

18. Roopesh R, Madhav MK. Orthodontic emergencies - a general practitioner's perspective. Health Science [serial online] 2013 [cited 2013 Aug 7]; 2(3): 1-13. Available from: URL: http://healthsciences.ac.in/jul-sep13/downloads/3.BPerspective.pdf

19. Souza RM, Menezes LM. Nickel, chromium and iron levels in the saliva of patients with stimulated fixed orthodontic appliances. The angle orthodontist [serial online] 2008 [cited 2013 Aug 1]; 78(2): 345-350. Available from: URL: http://www.angle.org/doi/pdf/10.2319/111 806-466.1

20. Faccioni F, Franceschetti P, Carpelloni M, Fracasso ME. In vivo study on metal release from fixed orthodontic appliances and DNA damage in oral mucosa cells. Am J Orthod Dentofacial Orthop [serial online] 2004 [cited 2013 Aug 1]; 125: 249. Available from: URL: http://www.studiofaccioni.it/img/pdf/orto dontico/SCAN0071.pdf

21. Bishara SE. Oral Lesions caused by an orthodontic retainer: a case report. Am J Orthod Dentofacial Orthop [serial online] 1995 [cited 2013 Aug 1]; 108(2): 115-7. Available from: URL: http://www.ajodo.org/article/S08895406(95)70073-0/pdf

22. Rasool G, Raza HA, Afzal F, Ijaz W, Shah SS. Frequency of bracket breakage $\&$ bond failure in patients, undergoing fixed orthodontic treatment at khyber college of dentistry, peshawar. Pakistan oral \& dental journal [serial online] 2013 [cited 2013 Aug 7]; 33(2): 299-302. Available from: URL: http://www.podj.com.pk/Aug_2013/PODJ -18.pdf

23. Arruda EP, Trevillato PC, Carmago ES, Woyceichoski IE, Machado AN, Vieira I, et al. Preclinical alterations of oral epithelial cells in contact with orthodontic appliances. Brazil [serial online] 2011 [cited 2013 Apr 21]: 299-303. Available from:

URL: http://biomed.papers.upol.cz/getrevsrc.ph p?identification $=$ public\&mag $=$ bio\&raid $=$ 172\&type $=$ fin \&ver $=2$ 
24. Anonim. Keputusan Menteri Kesehatan Republik Indonesia. Depkes RI [serial online] 2005 [cited 2013 Aug 7]. Available from: URL: http://perpustakaan.depkes.go.id:8180/bits tream//123456789/1290/1/KMK14151005.pdf

25. Gupta L, Chandavarkar V, Galgali SR, Mishra M. Clorhexidine, a medicine for all the oral diseases. GJMEDPH [serial online] 2012 [cited 2013 Oct 6]; 1(2): 438. Available from: URL: http://www.aften-hilfe.de/wpcontent/uploads/amlexanos-apthasol.pdf
26. Mostafa AAE, Ibrahem AEM. Management of aphthous ulceration with topical quercetin. CDJ [serial online] 2009 [cited 2013 Oct 6]; 25(1): 9-15. Available from:

URL: http://dentistry.cu.edu.eg/Files/CDJ/2009/ January\%202009/9-15-2.pdf

27. Savage NW, McCullough MJ. Topical corticosteroids in dental practice. Aus dent J [serial online] 2005 [cited 2013 Aug 1]; 50(2): 40-4. Available from: URL:

http://onlinelibrary.wiley.com/doi/10.111

1/j.1834-7819.2005.tb00385.x/pdf 